\title{
Review: omalizumab reduces asthma exacerbations and daily steroid use
}

Walker S, Monteil M, Phelan K, et al. Anti-lgE for chronic asthma. Cochrane Database Syst Rev

2003;(3):CD003559 (latest version 27 Aug 2002)

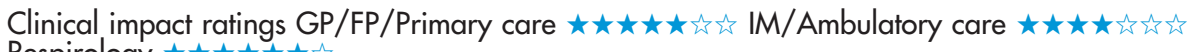

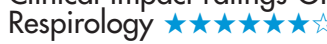

In patients with asthma, how effective is omalizumab, a recombinant humanised monoclonal antibody, in reducing asthma exacerbations and steroid use?

METHODS

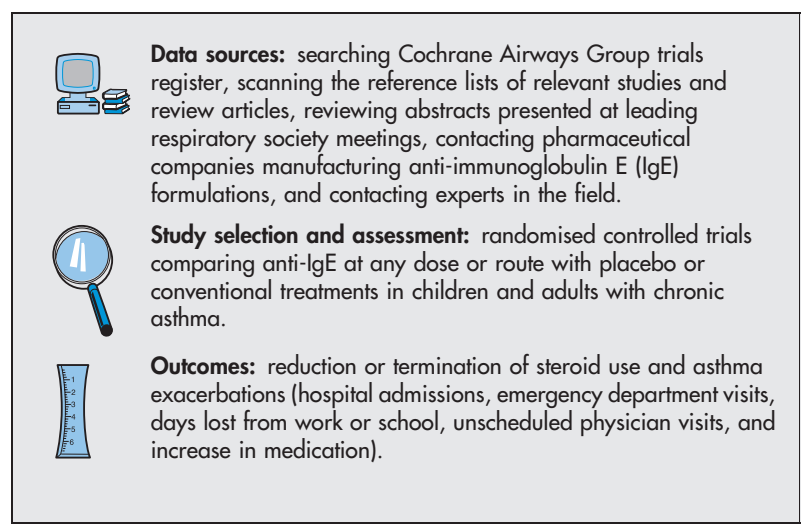

\section{MAIN RESULTS}

8 blinded, placebo controlled trials of fair to high quality met the inclusion criteria $(\mathrm{n}=2037)$. Omalizumab was administered by inhaler in 1 trial, intravenously in 3 trials, and subcutaneously in 4 trials. Results were reported for the stable steroid phase and the steroid reduction phase. During these phases, fewer patients who received omalizumab had $\geqslant 1$ asthma exacerbation (table). During the steroid reduction phase, more patients who received omalizumab discontinued inhaled steroid use or had $\geqslant 50 \%$ reduction in use (table). In both phases, patients who received omalizumab required less rescue medication and had fewer asthma symptoms $(\mathrm{p}<0.05)$. The 1 trial of inhaled omalizumab showed no difference from placebo in the outcomes measured.

\section{CONCLUSION}

In patients with asthma, intravenous or subcutaneous omalizumab reduces asthma exacerbations when used as adjunctive or steroid sparing therapy and reduces inhaled steroid use.

Abstract and commentary also appear in ACP Journal Club. Absiract and commentary also appear in $A C P$ Journal Club. For correspondence: Dr S Walker, National Respiratory Training Centre, Warwick, UK. s.walker@nrtc.org.uk

Source of funding: Garfield Weston Foundation UK.

\section{Commentary}

$7 \mathrm{~m}$ he role of monoclonal anti-lgE antibodies in clinical asthma management continues to evolve. Developed to neutralise and sequester circulating IgE antibodies in allergic people, this treatment seems to have more complex immunological effects than initially realised. Other beneficial effects include the down regulation of $\lg E$ receptors on mast cells and basophils, and altering allergen presentation to the immune system, thereby preventing sensitisation.

The meta-analysis by Walker et al confirms the clinical benefits of antilgE therapy, including the reduction of asthma exacerbations and decreasing the requirement for preventive inhaled steroids. Other studies show improvement in quality of life and lung function, suggesting a clinical benefit that reflects its wide ranging immunological effects. ${ }^{12}$ Furthermore, this benefit is evident in a range of asthma severity including severe asthma where lgE was thought to be less important. Hence, antilgE is not simply a steroid sparing treatment but seems to have other effects that cannot be achieved by inhaled steroids alone. Together with the fact that it can be injected every 2-4 weeks, it is a new method of asthma treatment with benefits that are additive and complementary to currently available medication.

However, the major limitation of anti-lgE currently is its cost to benefit ratio. The cost of the medication is currently about US $\$ 10000$ per year, which far exceeds other forms of asthma treatment. From this point of view, the cost to benefit ratio still favours inhaled steroids and long acting $\beta$ agonists as the foundation of achieving good asthma control in most patients. Nevertheless, there are patients maintained on optimal doses of these medications who continue to have poor asthma control or achieve it only with unacceptable side effects. In such patients, the direct and indirect costs of poor asthma control and frequent asthma exacerbations may well justify the cost of anti-lgE therapy. Looking ahead, if the cost of biotechnology and the price of this medication falls, it will be an adjunct to, and may well supplant, currently available inhaled steroids and long acting $\beta$ agonists even in patients with mild asthma. Frank Thien, MD, FRACP, FCCP

Alfred Hospital \& Monash University Melbourne, Victoria, Australia

1 Finn A, Gross G, van Bavel J, et al. Omalizumab improves asthma-related quality of life in patients with severe allergic asthma. J Allergy Clin Immunol 2003;111:278-84.

2 Busse W, Corren J, Lanier BQ, et al. Omalizumab, anti-lgE recombinant humanized monoclonal antibody, for the treatment of severe allergic asthma. J Allergy Clin Immunol 2001;108:184-90.

Omalizumab $v$ placebo for chronic asthma at up to 24 weeks*

\begin{tabular}{|c|c|c|c|c|c|c|}
\hline \multirow[b]{2}{*}{ Outcomes } & \multirow[b]{2}{*}{ Number of trials } & \multirow[b]{2}{*}{ Steroid phase } & \multicolumn{2}{|c|}{ Weighted event rates } & \multirow[b]{2}{*}{$\operatorname{RRR}(95 \% \mathrm{Cl})$} & \multirow[b]{2}{*}{ NNT (CI) } \\
\hline & & & Omalizumab & Placebo & & \\
\hline \multirow[t]{2}{*}{$\geqslant 1$ exacerbation } & $\begin{array}{l}3 \\
3\end{array}$ & $\begin{array}{l}\text { Stable steroid } \\
\text { Steroid reduction }\end{array}$ & $\begin{array}{l}14 \% \\
18 \%\end{array}$ & $\begin{array}{l}26 \% \\
33 \%\end{array}$ & $\begin{array}{l}46 \% \text { (33 to } 57) \\
44 \% \text { (33 to } 54 \text { ) }\end{array}$ & $\begin{array}{l}9(7 \text { to } 13) \\
7(6 \text { to } 10)\end{array}$ \\
\hline & & & & & RBI (CI) & \\
\hline $\begin{array}{l}\text { Steroid withdrawal } \\
\geqslant 50 \% \text { reduction in } \\
\text { steroid use }\end{array}$ & $\begin{array}{l}4 \\
4\end{array}$ & $\begin{array}{l}\text { Steroid reduction } \\
\text { Steroid reduction }\end{array}$ & $\begin{array}{l}40 \% \\
76 \%\end{array}$ & $\begin{array}{l}21 \% \\
56 \%\end{array}$ & $\begin{array}{l}85 \%(58 \text { to } 116) \\
35 \%(26 \text { to } 45)\end{array}$ & $\begin{array}{l}6(5 \text { to } 8) \\
5(5 \text { to } 7)\end{array}$ \\
\hline
\end{tabular}

*Abbreviations defined in glossary; RRR, RBI, NNT, and Cl calculated from data in article using a fixed effects model. 